\title{
Joë Bousquet: Paraplegia as a Poet's Plight and Challenge $\star$
}

\author{
A. Ohry, MD, K. Ohry-Kossoy, MA \\ Neurological Rehabilitation Department, Sheba Medical Center, Tel Hashomer \\ 52621 , Israel.
}

Through much of its duration, World War I was a protracted trench war with very heavy casualties. Among the many wounded, the spinal injured had a very small chance of survival and usually died within weeks. In France one of these few spinal survivors was Joë Bousquet, a young officer who became a renowned poet, and it is his unusual case which we review here. Our information is based on his own writings and on biographies. We have not been able to see his medical records, if they exist.

Bousquet was born in 1897 in Narbonne (Southern France). His father was an army doctor. At his birth a few hours of resuscitation were necessary to revive the baby. His nanny suddenly died as she held him in her arms when he was 10 months old. Bousquet knew these facts and felt his life was constantly in the shadow of death (Nelli, 1975): 'Bousquet has often expressed the feeling that he had not deserved life or that he had deserved not to be submitted to it' (Nelli, 1975).

Bousquet grew up in Carcassonne, also in the South of France. He was always against something, a rebellious and challenge-seeking character. As a youth he was already a very busy womaniser and used drugs. In 1916 he volunteered for combat duty in the French army and was first injured the following year. In those days he used cocaine, morphine, opium, and ether, mainly for thrills and much less as pain-killers. But he recovered and returned to the front, as was then usual.

In May 1918 Bousquet was again wounded in battle, this time very seriously. This is his own description: 'A bullet hit me in the chest, very close to the right shoulder, obliquely, going through my lungs and out through the tip of the left scapula; thus at the same time the bullet went through both my lungs and the frontal part of the vertebral body.' His injury level was D4-D5 and only one kidney was still functioning. During the first 3 months Bousquet was in a critical state. Gas gangrene threatened his life twice.

* This paper is dedicated with our respectful admiration to Professor Jean Starobinski of Geneva, who first suggested Joë Bousquet's case to us. 
Before we consider the course of his extraordinary, largely self-engineered rehabilitation, it is important to survey briefly the medical services existing for wounded French soldiers at the time. When the war started in 1914 all of the medical infrastructure in France was mobilised. At the front, injured men were sent to advanced dressing stations. Severe cases were quickly evacuated to field hospitals further back, and the worst to evacuation hospitals (Goodnow, 1935). From there they were taken to base-hospitals and later to convalescent camps. Those who recovered from their injuries went back to the front, and those who didn't went to specialised hospitals or 'invalid homes'. The care given to injured soldiers in France was generally good and up-to-date in the cleaning of wounds, debridement, and surgery after gunshot wounds (Graham, 1939; Garrison, 1929). The American assistance to France was also important: the United States were medically, although not militarily, ready for war in 1914. They sent massive medical assistance (mainly physicians and nurses) to France right from the beginning of hostilities. Thus, for example, a large American hospital was established in Neuilly, a suburb of Paris, and another one in Ris-Orangis, more to the south, to which Bousquet was first admitted after his spinal injury.

From there he was moved to Toulouse, then later closer to his home, to the local hospital in Carcassonne, where his uncle worked as surgeon. The physicians tried 'everything' on him and told him 'to react, to move, to pull himself around' (Nelli, 1975). From then on he was catheterised every 12 hours. Some sort of metallic corset was built for him, but he would not use it. With the years he developed dorsal kyphosis, most probably due to his paralysis. Bousquet knew spinal patients like himself lived on for a few months at most, and especially with the feeling of death breathing down his neck since he was born, he expected to die any day for a long time. Much later he would write about this period: 'I have lived the life of a condemned man. My survival is a medical

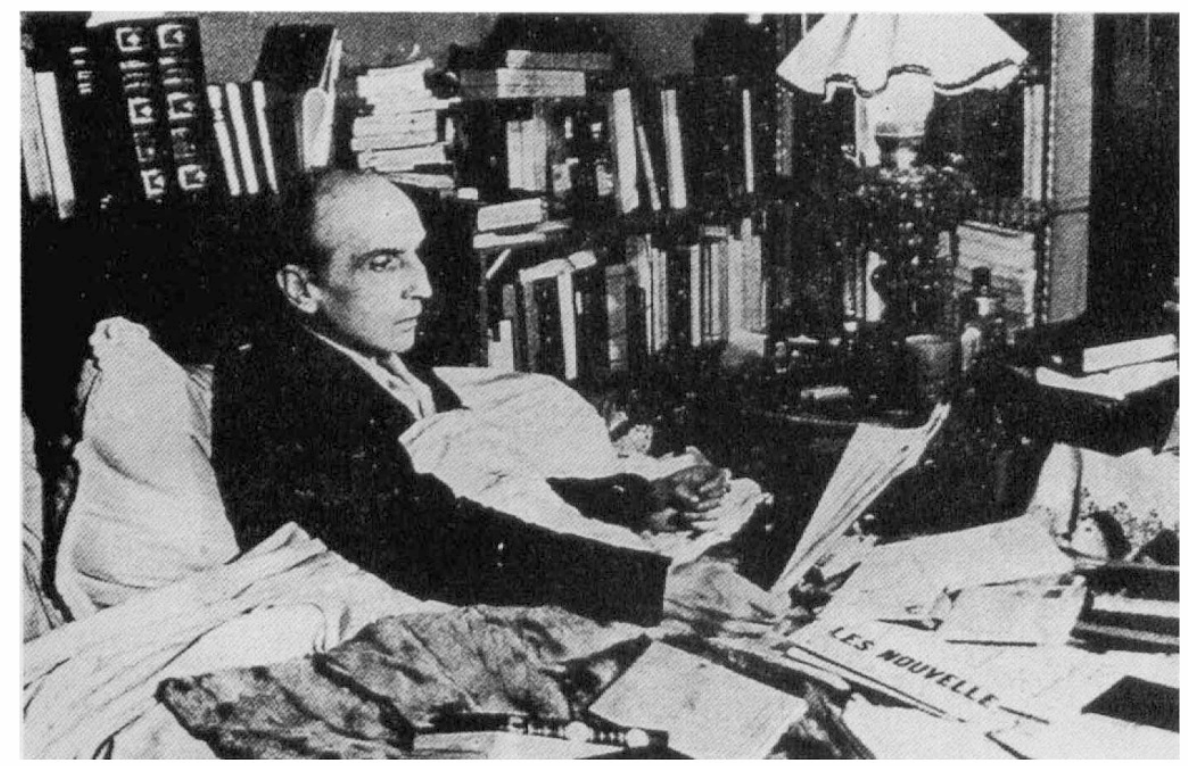

Figure 1 


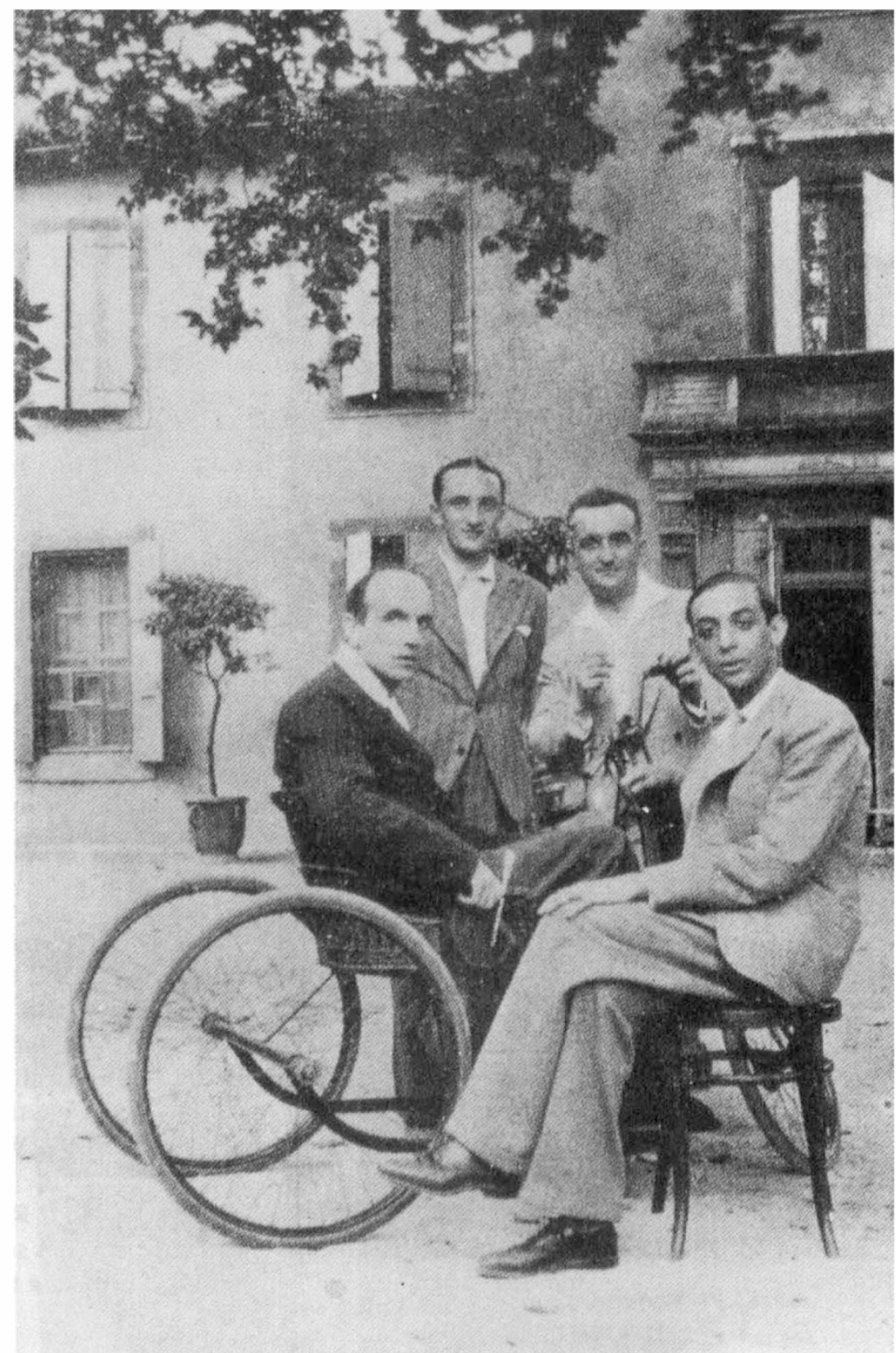

Figure 2

scandal, it has deceived everybody, and me in the first place. I have always turned my back on the future. Anyone who would have spoken of my 50 years would have been considered a fool' (in Massat, 1972).

But Bousquet did survive. More than a year and a half after his injury he was brought back home and a room was arranged for him on the ground floor 
of his parents' house. By then he had come to accept his state and decided to await death in his bed (Fig. 1), in which he stayed constantly, except for summer outings in a small hand-driven vehicle (Fig. 2) or in a friend's car. His vocation to literature was also born then. He surrounded himself with books, with paintings, with literary friends. He began writing a diary, essays, novels, poems. He corresponded with much of the French intellectual élite, contributed to cultural magazines, and turned his room into a Mecca of literature. From his bed he led an active social life and had a number of love affairs.

Inspired by Indian philosophy, by medieval scholastic thinking, close to his friends' surrealism, Bousquet used his peculiar and tragic situation as a paraplegic for his poetic and philosophical explorations. His subjects are the powers of language, the human condition, reality, life and death. The new outlooks resulting from his disability became the tools of his rehabilitation: 'The broken man is cursed and first of all by his own kin. When he can curse in his turn he is saved. Then he can again write with felicity, with humour, with wisdom ...' (Bousquet, 1939-1942).

We do not know exactly how Bousquet learned to avoid complications. The facts that he had several physicians in his family, that his relatives provided constant, loving care, that the Bousquets' were well off, and the mild mediterranean climate certainly contributed much to his successful rehabilitation. Despite occasional periods of illness and his continuing use of hallucinogenic drugs, Bousquet remained independent in activities of daily living and had relationships with women, about which we know very little. In his last years he suffered frequent bouts of uraemia and used opium to alleviate the pain. $\mathrm{He}$ died of chronic renal failure in 1950, at the age of 53, 32 years after his injury.

It is widely known to those involved in the field of paraplegia that until World War II most spinal cord injured patients died very soon after injury: 'Exceptionally, it may be possible to prolong a patient's life, although he is foredoomed to death' (Hull, 1917). Frankel (1971) has written that World War I was a period of experiment, observation, description, but therapeutic failure. Sir John Thomson-Walker (1937) wrote that 'anyone who has had to deal with large numbers of cases of spinal injury during 1914-18 will agree that the treatment of the bladder in these cases was one of the surgical failures of the War'. Most patients died of renal failure (Gowlland, 1941).

The breakthrough was made in World War II by Guttmann, Munro, Rusk, Gingras and others. Far from these pioneers, without medical or social rehabilitation facilities, Bousquet, the spirited poet, turned his paraplegia from plight into challenge.

\section{References}

André S, Juin H, Massat G 1972 Joë Bousquet: Poètes d'aujourd'hui. Seghers, Paris.

BousQuet J 1980 Papillon de neige - journal 1939-1942 Verdier, Lagrasse.

FRANKEL HL 1971 Development of the method of intermittent catheterization in the treatment of the bladder in acute paraplegia. Proceedings of the 8th Veterans Administration Conference on Spinal Cord Injury, Boston, Mass., pp 132-139.

GoodNow M 1935 Nursing in the World War, ch 18 in Outlines of Nursing History. WB. Saunders, 5th ed, Philadelphia. 
GARRISON FH 1929 Medicine in the World War and after, In: An Introduction to the History of Medicine. WB Saunders, 4th ed, Philadelphia, p. 790.

Gowlland EL 1941 The After Treatment of Paraplegic Patients following Injuries to the Spine. The British Medical fournal 1:814-815.

Graham H 1939 Today and Tomorrow. In: The Story of Surgery, ch 24, p 385. Doubleday, Doran \& Co, New York.

Hull AJ 1917 The Treatment of Gunshot Wounds of the Spine. Fournal of the Royal Army Medical Corps 28:66-70.

Nelli R 1975 Joë Bousquet, sa vie, son oeuvre. Albin Michel, Paris.

Thomson-Walker J 1937 The Treatment of the Bladder in Spinal Injuries in War. Proceedings of the Royal Society of Medicine 30:1233-1276. 